\title{
Quality of Life of Patients with Hypertension in Primary Health Care in Bandar Lampung
}

\author{
Sudewi Mukaromah Khoirunnisa* and Atika Dalili Akhmad
}

Department of Pharmacy, Institut Teknologi Sumatera, Jl. Terusan Ryacudu, Way Huwi, Jati Agung, Lampung Selatan, Lampung 35365

\author{
Info Article \\ Submitted: 26-02-2019 \\ Revised: 06-05-2019 \\ Accepted: $10-09-2019$ \\ *Corresponding author \\ Sudewi Mukaromah K \\ Email: \\ sudewi.mukaromah@ \\ fa.itera.ac.id
}

\begin{abstract}
The high prevalence of hypertension in Indonesia encourages studies related to how the quality of life of patients with hypertension. The purpose of this study was to measure the quality of life, identify, and explain factors related to the quality of life of patients with hypertension. The study design was an associative descriptive design using a cross-sectional study approach. The study subjects were all outpatient hypertensive patients from several health centers in Bandar Lampung. The instrument used in this study was the Indonesian SF-36. The data collected included the patient demographic characteristics, including gender, age, education, occupation, and marital status, and the fields related to the medical history of the study subjects, including the duration of hypertension, complications, and the number of antihypertensive drugs consumed. Data were analyzed using the bivariate analysis to see the association between two use of them. Multivariate analysis was conducted to study the association of several independent variables with one or several dependent variables. The results of the univariate analysis showed that age, marital status, duration of illness, complications, and the number of drugs consumed affected the quality of life of hypertensive patients $(\mathrm{p}<0.05)$. The results of multivariate analysis showed that the factors of age, marital status, and duration of hypertension were factors that influenced the physical domain. In contrast, whereas gender, marital status, duration of hypertension, complications, and the number of drugs were influential factors in the mental domain.
\end{abstract}

Keywords: Hypertension, Quality of Life, SF-36 physical and mental component summary

\section{INTRODUCTION}

Data from the World Health Statistics in 2012 revealed that as many as 57 million of the world's population died, of which 36 million (63\%) died of Non-Communicable Diseases (NCDs). Of the total deaths, an increase in blood pressure or hypertension is one of the main risk factors associated with $13 \%$ of population deaths. Hypertension is reported to be the 4th cause of premature death in developed and seventh countries in developing countries (Shah and Afzal, 2013). It is estimated that by 2025 , as many as 1.56 billion adults will suffer from hypertension (Bell $e t$ al., 2015). According to Riskesdas 2018, the prevalence of hypertension in Indonesia increases from $25.8 \%$ in 2013 to $32.2 \%$ in 2018 . The trend was similar in Lampung Province, with a $29.94 \%$ incidence in 2018, whereas the prevalence was 25\% in 2013 (Balitbangkes, 2018).

The main goal in the treatment of hypertension is to reduce long-term cardiovascular risk. Today, recent studies have focused on the quality of life for hypertensive patients to improve daily functioning, minimize physical and psychological suffering, and enable full participation in family and social life. Quality of life assessment is an essential study in hypertensive patients because this condition is a risk factor for cardiovascular disease, so it has a significant impact on the physical, social and mental domains that determine overall well-being and patient status. Both of these factors are highly correlated with other chronic diseases, such as diabetes and kidney disease (Theodorou et al., 2011; 
Zygmuntowicz, 2012). Most of these studies have shown that hypertension affects vitality, social function, mentality, health, emotions, and psychological functions (Theodorou et al., 2011). Patients with hypertension with complications have a low score, especially in the domain of the physical function, pain, and energy when measured using Bulpitt and Fletcher's Questionnaire and SF36 (Zygmuntowicz, 2012; Gusmão, 2009).

Based on this background, the measurement of quality of life is essential to assess the health status of patients with hypertension, especially factors related to therapy for patients with hypertension that can affect the quality of life. The increasing trend in the number of hypertensive sufferers in Lampung Province makes this study important so that it can improve treatment management and improve the quality of life for hypertensive patients.

\section{MATERIAL AND METHODS}

The research method used in this study was a descriptive correlation using a cross-sectional study approach. A Descriptive correlation aims to describe the association between variables. Crosssectional research was a study conducted without treatment of respondents, and this study aims to study whether there was an association between independent and bound variables, where both types of variables were observed at the same time (Arikunto, 2006). Understanding at the same time here does not mean that observation or questioning on all objects for all variables is done at one time, but each subject was observed or questioned only once, both for the independent variable and the dependent variable.

\section{Research subject}

The procedure for taking subject research was done by non-probability sampling with the accidental sampling technique, which was done by taking respondents who happen to be available or meet the research inclusion criteria. The study subjects were all hypertensive patients who underwent outpatient care at eight health centers in Bandar Lampung. The inclusion criteria were patients with a diagnosis of hypertension with or without complications, 20-75 years old, patients undergo outpatient care, can read and understand the questionnaire, and willing to participate in research. The exclusion criteria were patients who did not complete the questionnaire. The sample size was determined by using a minimum sample formula (n) (Hosmer et al., 1997). The formula to calculate sample size in this research was:

$n=\frac{Z_{1-\frac{\alpha}{2}}^{2} \cdot p \cdot(1-p)}{d d^{2}}$

$n$ : minimum sample size; $\mathrm{Z}_{1-\alpha / 2}$ degree of confident $\left(\mathrm{Z}_{1-\alpha / 2}=1.96\right)$; P: population $(\mathrm{p}=0.5)$; $\mathrm{d}$ : deviation $(d=0.07)$. In this research, the number of subjects was 134 patients.

\section{Research ethics}

This research was conducted after obtaining permission to research ethics committee approval by the Medical and Health Research Ethics Committee Faculty of Medicine Gadjah Mada University No. KE/FK/0963/EC/2018

\section{Data analysis}

The categorical data such as gender, age, education, occupation, marital status, duration of hypertension, complications, and the number of antihypertensive drugs consumed were explained by percentage or proportion measures. Bivariate analysis was conducted to evaluate the association between variables, namely the association of independent variables (gender, age, education, occupation, marital status, obesity, duration of hypertension, complications, and the number of antihypertensive drugs consumed) with the dependent variable (quality of life). In this study, the quality of life domain in the SF-36 questionnaire was summarized as Physical Component Summary (PCS) and Mental Component Summary (MCS). The significance level used is $5 \%(\alpha=0.05)$, with the value of the confidence interval set is $95 \%$. The association between independent variables with one dependent variable was analyzed using multivariate analysis.

\section{RESULT AND DISCUSSION \\ Patient demographic data}

This study was conducted on eight health centers in Bandar Lampung City from April to July 2018, obtained 134 hypertensive patients (Table I). Illustrates that most hypertensive patients in health centers in Bandar Lampung are aged 60-81 years, are female, have partners, graduate from high school, are retired, earn Rp. 3,000,000 - Rp. $4,000,000$, had suffered from hypertension for more than ten years, had complications, and the number of hypertension drugs consumed was two types (Table I). 
Table I. Patients' demographic data

\begin{tabular}{llrr}
\hline & Variable & N & \% \\
\hline Age & $42-50$ & 35 & 26.12 \\
& $51-59$ & 37 & 35.07 \\
Sex & $60-81$ & 52 & 38.81 \\
\multirow{3}{*}{ Marital Status } & 61 & 45.52 \\
\multirow{4}{*}{ Education } & Female & 73 & 54.48 \\
& Male & 84 & 62.69 \\
Occupation & With Partner & 50 & 37.31 \\
& With Out Partner & 130 & 97.01 \\
& School & 4 & 2.98 \\
Income & Not School & 81 & 60.45 \\
& Working & 19 & 14.18 \\
& Not Working & 34 & 25.37 \\
& Retired & 13 & 9.70 \\
& $<$ Rp 1,000,000 & 19 & 14.18 \\
Duration of & Rp 1,000,000-Rp. 2,000,000 & 41 & 30.60 \\
Hypertension & Rp 2,000,000-Rp. 3,000,000 & 49 & 36.57 \\
Complication & Rp 3,000,000-Rp. 4,000,000 & 12 & 8.96 \\
& $>$ Rp 4,000,000 & 83 & 61.94 \\
Number Drug Use & Y10 Years & 51 & 38.06 \\
& Yes Years & 21 & 15.67 \\
& No & 113 & 84.33 \\
& 2 & 47 & 35.07 \\
& $>2$ & 79 & 58.96 \\
\hline
\end{tabular}

The results showed that the distribution of hypertensive patients in Bandar Lampung City health centers in 2018, out of a total of 134 patients, were $54.48 \%$ female. This result is following the study of Sari et al. (2017) that hypertensive patients are dominated by women (73\%). Based on age, the age distribution of hypertensive patients in this study showed $38.81 \%$ aged $60-81$ years. Blood pressure increases with age, and hypertension is a disease that mostly affects the elderly. The incidence of hypertension in the elderly has a high prevalence of $60-80 \%$ at the age of 65 years (Kustanti, 2012). Based on job characteristics, there were $25.37 \%$ of hypertensive patients who were retirees. This result is following Annisa's study (2013), which states that the majority of subjects do not work. The income of hypertensive patients in this study showed that $36.57 \%$ had sufficient income. Individuals with sufficient socioeconomic status will be able to provide all the facilities needed to fulfill their daily needs.

Conversely, individuals with low socioeconomic status will experience difficulties in fulfilling their life needs. Low income will be related to the use of health services and prevention. Someone does not take advantage of existing health services, perhaps because they do not have enough money to buy medicine or pay transportation to the hospital (Notoatmodjo, 2012).

\section{Quality of life of hypertension patients}

The average score for PCS was 39.32, and MCS was 29.53 (Figure 1). Mental domains affect the quality of life of hypertensive patients more than the physical domain caused by a diagnosis of the disease, the use of long-term therapy, and symptoms of hypertension. This result is in line with the research conducted by Bhandari et al. (2016) with an average score of PCS of 48.22 and MCS of 38.74. The physical domain was more dominant than the mental domain. Analysis of the association of age to the quality of life of hypertensive patients was found that patients aged 60-81 had a lower quality of life than other age groups (Table II). The results of statistical tests using ANOVA obtained p values below 0.05, so it can be concluded that there is an association 


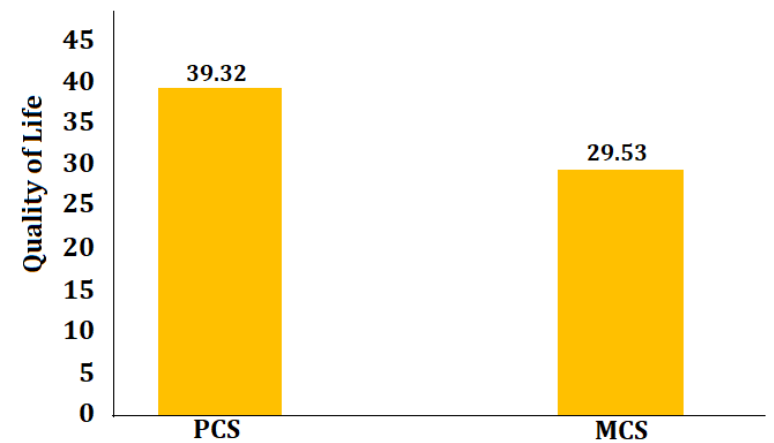

Figure 1. PCS and MCS score of hypertension patients

Table II. The relationship between PCS, patients' demographic data and clinical variable

\begin{tabular}{|c|c|c|c|c|c|c|c|}
\hline & Variable & $\begin{array}{l}\text { Number } \\
(n=134)\end{array}$ & Average & SE & $\begin{array}{c}\text { Test Statistic } \\
\text { Value }\end{array}$ & $\mathbf{P}$ & $95 \%$ CI \\
\hline \multirow[t]{3}{*}{ Age } & $42-50$ & 35 & 47.89 & 0.74 & $34.116^{\mathrm{a}}$ & $0.000^{c}$ & $54.32-58.43$ \\
\hline & $51-59$ & 47 & 40.45 & 0.87 & & & $45.67-47.11$ \\
\hline & $60-81$ & 52 & 32.18 & 0.95 & & & $39.29-46.88$ \\
\hline \multirow[t]{2}{*}{ Sex } & Male & 61 & 48.98 & 0.86 & $4.32^{\mathrm{b}}$ & $0.17^{c}$ & 2.56-6.71 \\
\hline & Female & 73 & 46.21 & 0.78 & & & \\
\hline \multirow[t]{2}{*}{ Marital Status } & With partner & 84 & 52.87 & 0.48 & $6.89^{b}$ & $0.000^{c}$ & $6.71-9.43$ \\
\hline & Without partner & 50 & 43.11 & 0.73 & & & \\
\hline \multirow[t]{2}{*}{ Education } & School & 130 & 43.56 & 0.81 & $9.54^{b}$ & $0.08^{c}$ & $5.23-6.40$ \\
\hline & Not School & 4 & 39.80 & 0.69 & & & \\
\hline \multirow[t]{3}{*}{ Occupation } & Working & 81 & 41.48 & 0.29 & $7.46^{b}$ & $1.32^{\mathrm{c}}$ & $3.76-6.11$ \\
\hline & Not working & 19 & 37.11 & 0.52 & & & \\
\hline & Retired & 34 & 46.76 & 0.73 & & & \\
\hline \multirow[t]{5}{*}{ Income } & $<$ Rp. $1,000,000$ & 13 & 43.51 & 0.60 & $3.43^{b}$ & $0.12^{c}$ & $1.32-3.19$ \\
\hline & Rp. $1,000,000-$ Rp.2,000,000 & 19 & 44.80 & 0.53 & & & \\
\hline & Rp.2,000,000-Rp.3,000,000 & 41 & 45.76 & 0.41 & & & \\
\hline & Rp.3,000,000-Rp.4,000,000 & 49 & 47.11 & 0.32 & & & \\
\hline & $>$ Rp. $4,000,000$ & 12 & 45.54 & 0.46 & & & \\
\hline \multirow{4}{*}{$\begin{array}{l}\text { Duration of } \\
\text { hypertension } \\
\text { Complications }\end{array}$} & $<10$ years & 83 & 57.30 & 0.58 & 5.92 & $0.000^{c}$ & $38.71-45.21$ \\
\hline & $>10$ years & 51 & 39.08 & 0,32 & & & $34.04-44.70$ \\
\hline & No & 21 & 36.78 & 0.12 & $3.90^{\mathrm{b}}$ & $0.001^{c}$ & $13.67-19.05$ \\
\hline & Yes & 113 & 44.63 & 0.39 & & & \\
\hline \multirow{2}{*}{$\begin{array}{l}\text { The number } \\
\text { of drugs used }\end{array}$} & 1 & 47 & 34.67 & 0.54 & $3.19^{b}$ & $0.000^{c}$ & $2.76-5.93$ \\
\hline & 2 & 79 & 45.90 & 0.31 & & & \\
\hline
\end{tabular}

$\mathrm{a}=\mathrm{f}$-value $\left(\right.$ ANOVA); ${ }^{\mathrm{b}}=\mathrm{t}$-value $(\mathrm{t}$-test $){ }^{\mathrm{c}}{ }^{\mathrm{s}}=$ significant $(\mathrm{p}<0.05), \mathrm{CI}=$ Confidence Interval

between age and quality of life of hypertensive patients for physical domains. The similar result was found in marital status (CI: 6.71-9.43, p<0.05). Meanwhile, the test of association was not significant between PCS and sex (CI: 2.56-6.71, p:0.17), education (CI:3.76-6.11, p:0.08, occupation (CI:3.76-6.11, p:1.32), and income (CI:1.32-3.19, $\mathrm{p}: 0.12)$. PCS has indicated that association between duration of hypertension (CI:38.71-45.21, $\mathrm{p}<0.05$ ), complications (CI:13.67-19.05, p<0.05), and the number of drugs used $(\mathrm{CI}: 2.76-5.93, \mathrm{p}<0.05)$ (Table II).

Age, sex, and marital status have an association with the mental domain. However, education, occupation, and income do not affect the quality of life in terms of the mental domain of hypertension patients (Table III).

Multivariate analysis result of factors in association of PCS score (Table IV). Age (CI:-1.93 to 
Table III. The relationship between MCS, patients' demographic data and clinical variable

\begin{tabular}{|c|c|c|c|c|c|c|c|}
\hline & Variable & $\begin{array}{l}\text { Number } \\
(n=134)\end{array}$ & Average & SE & $\begin{array}{c}\text { Test Statistic } \\
\text { Value }\end{array}$ & $\mathbf{P}$ & $95 \%$ CI \\
\hline \multirow[t]{3}{*}{ Age } & $42-50$ & 35 & 47.03 & 0.65 & $29.543^{\mathrm{a}}$ & $0.000^{c}$ & $42.19-48.72$ \\
\hline & $51-59$ & 47 & 40.51 & 0.45 & & & $43.70-47.19$ \\
\hline & $60-81$ & 52 & 33.79 & 0.21 & & & $39.02-41.59$ \\
\hline \multirow[t]{2}{*}{ Sex } & Male & 61 & 46.16 & 0.37 & $3.09 \mathrm{~b}$ & $0.000^{c}$ & 4.59-7.32 \\
\hline & Female & 73 & 40.08 & 0.29 & & & \\
\hline \multirow[t]{2}{*}{ Marital status } & With partner & 84 & 53.32 & 0.34 & $8.80^{\mathrm{b}}$ & $0.001^{\mathrm{c}}$ & $5.40-7.98$ \\
\hline & Without partner & 50 & 43.40 & 0.48 & & & \\
\hline \multirow[t]{2}{*}{ Education } & School & 130 & 44.03 & 0.32 & $7.94^{\mathrm{b}}$ & $0.14^{c}$ & $7.29-9.49$ \\
\hline & Not School & 4 & 41.32 & 0.72 & & & \\
\hline \multirow[t]{3}{*}{ Occupation } & Working & 81 & 41.27 & 0.56 & $3.41^{b}$ & $2.91^{c}$ & $4.41-5.07$ \\
\hline & Not working & 19 & 36.70 & 0.32 & & & \\
\hline & Retired & 34 & 45.98 & 0.48 & & & \\
\hline \multirow[t]{5}{*}{ Income } & $<$ Rp. $1,000,000$ & 13 & 44.19 & 0.39 & $2.73^{b}$ & $0.32^{c}$ & $1.56-3.50$ \\
\hline & Rp.1,000,000-Rp.2,000,000 & 19 & 44.87 & 0.48 & & & \\
\hline & Rp.2,000,000-Rp.3,000,000 & 41 & 45.32 & 0.56 & & & \\
\hline & Rp.3,000,000-Rp.4,000,000 & 49 & 46.97 & 0.91 & & & \\
\hline & $>$ Rp. $4,000,000$ & 12 & 45.49 & 0.76 & & & \\
\hline \multirow{2}{*}{$\begin{array}{l}\text { Duration of } \\
\text { hypertension }\end{array}$} & $<10$ years & 83 & 58.43 & 0.23 & $3.12^{\mathrm{a}}$ & $0.000^{c}$ & $33.93-40.51$ \\
\hline & $>10$ years & 51 & 37.01 & 0.91 & & & $35.23-47.98$ \\
\hline \multirow[t]{2}{*}{ Complications } & No & 21 & 43.23 & 0.34 & $2.92^{\mathrm{b}}$ & $0.001^{\mathrm{c}}$ & $25.64-32.53$ \\
\hline & Yes & 113 & 38.23 & 0.60 & & & \\
\hline \multirow{3}{*}{$\begin{array}{l}\text { The number } \\
\text { of drugs used }\end{array}$} & 1 & 47 & 43.90 & 0.30 & $3.04^{\mathrm{b}}$ & $0.000^{c}$ & $1.79-3.9$ \\
\hline & 2 & 79 & 39.32 & 0.21 & & & \\
\hline & $>2$ & 8 & 34.96 & 0.83 & & & \\
\hline
\end{tabular}

a=f-value (ANOVA); ${ }^{b}=\mathrm{t}$-value $\left(\mathrm{t}\right.$-test) ${ }^{\mathrm{c}}=$ significant $(\mathrm{p}<0.05), \mathrm{CI}=$ Confidence Interval

Table IV. Multivariate analysis of factors contributing to the quality of life of hypertension patients in the physical domain and mental domain

\begin{tabular}{llcccc}
\hline Variable & Co-efficient & Beta & P & 95\% CI \\
\hline \multirow{2}{*}{ PCS } & Age & -3.176 & -0.129 & $0.000^{\mathrm{a}}$ & $-1.93-2.74$ \\
& Marital Status & -4.981 & -0.291 & $0.000^{\mathrm{a}}$ & $-5.32-0.17$ \\
& Duration of hypertension & 0.736 & -0.437 & $0.000^{\mathrm{a}}$ & $-1.98-2.39$ \\
& Complications & -1.762 & -0.120 & 0.245 & $-2.65-1.98$ \\
\multirow{4}{*}{ MCS } & -0.913 & 0.047 & 0.152 & $-2.37-1.74$ \\
& The number of drugs used & -2.146 & -0.312 & 0.078 & $-1.72-2.43$ \\
& Age & -2.672 & -0.483 & $0.000^{\mathrm{a}}$ & $-2.49-3.21$ \\
& Sex & -3.901 & -0.324 & $0.000^{\mathrm{a}}$ & $-5.45-0.71$ \\
& Marital Status & 0.931 & -0.472 & $0.001^{\mathrm{a}}$ & $-1.43-2.18$ \\
& Duration of hypertension & -1.821 & -0.207 & $0.001^{\mathrm{a}}$ & $-2.39-1.40$ \\
& Complications & -0.703 & 0.032 & $0.000^{\mathrm{a}}$ & $-2.30-1.21$ \\
\hline
\end{tabular}

$-2.74, \mathrm{p}<0.000)$, marital status (CI:-5.32 to -0.17 , $\mathrm{p}<0.000$ ), and duration of hypertension (CI:-1.98 to $-2.39, \mathrm{p}<0,000$ ) has a significant association with physical domains. The result of multivariate regression in mental domain shows that gender (CI:-2.49 to $-3.21, \mathrm{p}<0.000$ ), marital status CI:-5.45 to $-0.71, p<0,000)$, duration of hypertension CI:1.43 to $-2.18, \mathrm{p}<0.001)$, complications CI:-2.39 to $1.40, \mathrm{p}<0.001$ ), and the number of drugs used CI:2.30 to $-1.21, \mathrm{p}<0.000)$ contributed significantly to quality of life. In this study, age was identified as the main factor of QoL in the physical domain. With 
increasing age, there is an increasing illness due to affect not only physiological and functional changes but also physical aspects. The economic problem is related to the ability to access the appropriate treatment for the illness. Some studies reveal that older age is mostly related to lower quality of life because they have lower scores in physical and mental domains. This result is consistent with other studies where lower scores were identified in PCS (Bardage et al., 2001; Youssef et al., 2005; Zygmuntowicz, 2012). In this study, age is a significant factor contributing to the physical domain, while it is not significant in the mental domain. Gender is a factor that influences the quality of life of hypertensive patients in the mental domain with a higher quality of life in men than women. Theoretically, women are weaker physically and easily fatigued. This study is consistent with other studies that women have a low quality of life in the mental domain (Castro et al., 2012; Erickson et al., 2004).

Marital status has a significant score as a factor that influences the quality of life of hypertensive patients in the physical and mental domains. Patients who live with partners have a better quality of life than those who live alone. This finding may be influenced by the support they might receive from their partners, and they do not have someone they want to talk to and ask for help. Psychosocial health problems and feelings of loneliness are more common among those who live alone than those who live with their families because of a lack of emotional support in the family and society. This finding is consistent with several studies that reveal that married patients who live together with their partners have a higher score than those who do not live with their partners (Bardage et al., 2001; Youssef et al., 2005; Ha et al., 2014; Carvalho et al. 2013; Al-Mandhari et al., 2011). In this study, the duration of hypertension is factors that influence the quality of life in hypertensive patients in both the physical and mental domains in multivariate analysis. Several studies $[22,30,31,33,34]$ show significant findings with the duration of disease (Carvalho et al., 2013; Al-Mandhari et al., 2011; Holt et al., 2010; Erickson et al., 2004; Zygmuntowicz, 2013). This study shows a significant association between MCS with complications and the number of drugs. The results of this study are consistent with several studies that show significant differences in the reporting of symptomatic patients higher in MCS (Holt et al., 2010; Erickson et al., 2004; Ogunlana et al., 2009).

\section{Study limitation}

This study used SF-36 as a universal tool to measure the quality of life of hypertension patients. SF-36 is a widely used instrument to measure the quality of life of patients in various aspects such as social, function, emotional, and physical, which has good validity and reliability. Nevertheless, the hypertension-specific tool is needed to assess the quality of life in order to provide more detail information and responsive result.

\section{CONCLUSION}

According to the result of this research, the quality of life of hypertension patients in the mental domain was lower than the physical domain. Age and marital status were the most influential factor for both in Mental Component Summary and Physical Component Summary. The quality of life in the physical domain was influenced by age, marital status, and duration of hypertension. However, gender, marital status, duration of the disease, complication, and the number of drugs used were factors that significantly influenced the mental domain.

\section{ACKNOWLEDGEMENT}

This research was funded by The Ministries of Research, Technology, and Higher Education of Indonesia. The authors also thank all parties, particularly staff in 8 health centers in Bandar Lampung.

\section{REFERENCES}

Al- Mandhari A., Al-Zakwani I., Al- Hasni A. and Al-Sumri N., 2011, Assessment of Perceived Health Status in Hypertensive and Diabetes Mellitus Patients at Primary Health Centers in Oman, Int J Prev Med, 2(4):256-63.

Annisa, 2013, Penilaian Kualitas Hidup pada Usia Lanjut Dengan EQ-5d Di Klub Jantung Sehat Kelurahan Pondok Kelapa Dan Faktor-faktor Yang Mempengaruhi, Tesis, Fakultas Kedokteran Universitas Indonesia, Jakarta.

Arikunto S., 2006, Prosedur Penelitian Suatu Pendekatan Praktik, Jakarta: Rineka Cipta.

Badan Penelitian dan Pengembangan Kesehatan, 2013, Riset Kesehatan Dasar 2013, Jakarta: Kementerian Kesehatan RI.

Bardage C. and Isacson DGL, 2001, Hypertension and Health-related Quality of Life: An Epidemiological Study in Sweden, Journal Clinical Epidemiology, 54:172. 
Bell K., Twiggs J., Olin BR., 2015, Hypertension: The Silent Killer: Updated JNC-8 Guideline Recommendations, Summer 2015: Continuing Education, Alabama Pharmacy Association.

Bhandari N., Bhusal BR., Takma KC., Lawot I., 2016, Quality of Life of Patient with Hypertension in Kathmandu, International Journal of Nursing Sciences, 3, 379-384.

Carvalho MV., Siqueira LB., Sousa ALL., Jardim PC., BV., 2013, The Influence of Hypertension on Quality of Life, Arquivos Brasileiros de Cardiologia, Vol. 100, No. 2, 164-174.

Castro SMdO., Coutinho RMC., 2012, Quality of Life of Patients with Hypertension, J Health Sci Inst, 30(2):134-9.

Erickson SR., Williams BC, Gruppen LD., 2004, Relationship Between Symptoms and Health-related Quality of Life in Patients Treated for Hypertension, Pharmacotherapy 24(3):344-50.

Gusmão, J., L., Mion, Jr. D., Pierin, A., M., G., 2009, Health-related Quality of Life and Blood Pressure Control in Hypertensive Patients with and Without Complications, Clinics, Volume 64(7), 619-28.

Ha NT., Duy HT., Le NH., Khanal V., Moorin R., 2014, Quality of Life Among People Living with Hypertension in A Rural Vietnam Community, BMC Public Health, 14:833.

Holt EW., Muntner P., Joyce C.J., Webber L., KrouselWood MA., 2010, Health-Related Quality of Life and Antihypertensive Medication Adherence Among Older Adults, Age Ageing, 2;39:481-7.

Hosmer DW., Hosmer T., Le Cessie S., Lemeshow S. (1997) A Comparison of Goodness-of-Fit Tests for the Logistic Regression Model. Statistics in Medicine, 16, 965-980.

Kustanti N., 2012, Kualitas Hidup Lansia dengan Hipertensi di Wilayah Kerja Puskesmas Karang Malang Kabupaten Sragen, Skripsi, Ilmu Kesehatan Universitas Muhammadiyah Surakarta, Surakarta.
Notoatmodjo, Soekidjo, 2012, Promosi Kesehatan dan Perilaku Kesehatan. Jakarta. Rineka Cipta.

Ogunlana MO., Adedokun B., Dairo MD., Odunaiya N., 2009, Profile and Predictor of Healthrelated Quality of Life Among Hypertensive Patients in South-Western Nigeria, BMC Cardiovasc Disord, 9:25.

Sari A., Lolita, Fauzia. 2017. Pengukuran Kualitas Hidup Pasien Hipertensi di Puskesmas Mergangsan Yogyakarta Menggunakan European Quality of Life 5 Dimensions (EQ5D) Questionnaire dan Visual Analog Scale (VAS), Jurnal Ilmiah Ibnu Sina, 2(1), 112.

Shah A., Afzal M. 2013, Prevalence of Diabetes and Hypertension and Association with Various Risk Factors among Different Muslim Populations of Manipur India, Journal of Diabetes and Metabolic Disorders, 12:52

Theodorou M., Kaitelidou D., Galanis P., Middleton N., Theodorou P., Stafylas P., Siskou O., Maniadakis N., 2011, Quality of Life Measurement in Patients with Hypertension in Cyprus, The Hellenic Journal of Cardiology, Volume 52: 407-415.

Widjaja FF., Santoso LA., Barus NRV., Pradana GA., Estetika C., 2013, Prehypertension and Hypertension Among Young Indonesian Adults at a Primary Health Care in a Rural Area, Medical Journal of Indonesia, Vol. 22, No. 1

Youssef RM., Moubarak II., Kamel MI., 2005, Factors Affecting the Quality of Life of Hypertensive Patients, Eastern Mediterranean Health Journal, Vol. 11, 109-18.

Zygmuntowicz M., Owczarek A., Elibol A., Chudek J., 2012, Comorbidities and The Quality of Life in Hypertensive Patients, Polish Archives of Internal Medicine, 122, 7-8.

Zygmuntowicz M., Owczarek A., Elibol A., Olszanecka-Glinianowicz M., Chudek J., 2013, Blood Pressure for Optimal Healthrelated Quality of Life in Hypertensive Patients, J Hypertens, 31(4):830-9. 